\title{
Imatinib Use in Pregnancy
}

\section{Hamilelikte İmatinib Kullanımı}

\author{
Michael J Webb ${ }^{1}$, Debbie Jafta ${ }^{2}$ \\ ${ }^{1}$ Division of Clinical Haematology, Department of Internal Medicine, Faculty of Health Sciences, \\ University of the Free State, Bloemfontein, South Africa \\ ${ }^{2}$ Department of Haematology and Cell Biology, National Health Laboratory Service, Faculty of Health Sciences, \\ University of the Free State, Bloemfontein, South Africa
}

\begin{abstract}
The outcome in patients with chronic myeloid leukemia (CML) has dramatically improved over the last decade due to the widespread use of novel tyrosine kinase inhibitors such as imatinib. As overall survival has improved, the number of women with CML that wish to become pregnant has increased. As such, attending physicians are faced with a dilemma - continue life-prolonging medication to treat the cancer, or interrupt its use due to its potential teratogenicity. Herein we describe 2 CML patients that gave birth. Case 1 was managed via substitution of imatinib with interferon. The patient's child underwent genetic evaluation at age 3 years, achieved normal developmental milestones, and despite being shorter than his peers was proportional. In terms of morphology, the child had clinodactyly, short fifth fingers, and slightly downward slanting palpebral fissures, but otherwise appeared normal. In case 2 imatinib was continued throughout the pregnancy. This patient's child underwent postpartum evaluation by a geneticist and was observed to be morphologically normal, except for clinodactyly and low-set ears.
\end{abstract}

Key Words: Imatinib, Tyrosine kinase inhibitors, Chronic myeloid leukemia, Pregnancy

\section{Özet}

Kronik myeloid lösemili (KML) hastaların sonuçları son on yıl içinde yeni tirozin kinaz inhibitörlerinin yaygın olarak kullanılmasıyla dramatik bir düzelme göstermiştir. Daha iyi genel sağkalımla hamile kalan KML hastası kadınların sayısında bir artış görülmüştür. İlgili doktor bir ikilemle karşı karşıyadır: kanseri tedavi etmek için yaşamı uzatıcı ilaçları devam ettirme veya olası teratojenisite nedeniyle kullanımlarını kesme. KMLli kadınlarda iki başarılı hamileliği sunuyoruz . Birinci vaka imatinib yerine interferon kullanılmasıyla takip edildi. Bu vakada çocuğa üç yaşındayken genetik değerlendirme yapıldı. Normal gelişimsel referans noktalarına ulaşmıştı ama yaşıtlarından fiziksel olarak daha küçüktü. Ancak orantılar normaldi. Morfolojik olarak klinodaktili, kısa 5. parmaklar ve palpebral fissürlerde hafif aşağıya doğru eğim olması dışında normal görünüyordu. İkinci vakada imatinib hamilelik boyunca devam ettirildi. Çocuğa postpartum bir genetik uzmanı tarafından değerlendirme yapıldı ve klinodaktili ve alçak yerleşimli tırnaklar dışında morfolojik olarak normal bulundu.

Anahtar Sözcükler: İmatinib, Tirozin kinaz inhibitörleri, Kronik myeloid lösemi, Hamilelik

Address for Correspondence: Mike WEBB, M.D.,

Department of Internal Medicine (G73), Faculty of Health Sciences, University of the Free State, PO Box 339, Bloemfontein 9300, South Africa

Phone: +27514053154 E-mail: webbmj@ufs.ac.za 


\section{Introduction}

Chronic myeloid leukemia (CML) is a myeloproliferative neoplasm associated with the Philadelphia chromosome. The Philadelphia chromosome results from the reciprocal translocation of chromosomes 9 and 22, leading to production of the BCR-ABL fusion protein. This fusion protein is thought to be the initiating event in the pathogenesis of CML. Inhibition of this protein was a logical therapeutic target and led to the development of imatinib mesylate (Gleevec ${ }^{\circledR}$, Novartis, Basel, Switzerland), a firstgeneration tyrosine kinase inhibitor.

The International Randomized Study of Interferon Versus STI571 (IRIS) showed conclusively that imatinib 400 mg was superior to the standard care offered at the time of the study [1]. To date, imatinib remains the optimal firstline therapy for patients with CML. In terms of monitoring patients treated with imatinib, time-related improvement in hematological, cytogenetic, and molecular markers of disease is important [2]. To achieve optimal outcome, imatinib should be administered at $400 \mathrm{mg}$ po /day [3]. Treatment compliance is important and dose interruptions have a negative impact on outcome [4].

With the advent of imatinib, CML has been transformed from a universally fatal disease to a disease with an estimated 7-year overall survival of 86\% [5]. Along with the increase in the number of CML patients experiencing long-term survival come additional challenges, such as an increase in the number of female patients that want to become pregnant. This poses a potential predicament for attending physicians, as based on limited data available in human and animal models, it is recommended that imatinib (a life-saving therapy) not be administered to pregnant women [6]. Herein we describe 2 female CML patients treated with imatinib therapy that subsequently gave birth.

\section{Case 1}

A newly married 26-year-old female presented to her general physician with headache, depression, and splenomegaly. She was subsequently diagnosed with Philadelphia chromosome-positive chronic-phase CML in November 2004. Her full blood count findings were as follows: WBC count: 300 x 109/L (normal range: 4.0-11.0 x 109/L); Hb: $10.0 \mathrm{~g} / \mathrm{dL}$ (normal range: $11.5-16.0 \mathrm{~g} / \mathrm{dL}$ ), Plt count: $249 \times 10^{9} / \mathrm{L}$ (normal range: $150-450 \times 10^{9} / \mathrm{L}$ ). The differential count included a neutrophil count of 90 x $10^{9} / \mathrm{L}$ (normal range: $2.0-7.5 \times 10^{9} / \mathrm{L}$ ) and an increase in immature granulocytes. Her peripheral blast count was 3\% (normal value: 0\%). The patient's bone marrow was hypercellular without an increase in the blast count.
Clinical examination showed that her spleen was enlarged to $6 \mathrm{~cm}$ below the costal margin. She was initially started on hydroxyurea 2 g/d p.o. until imatinib could be procured via the Glivec ${ }^{\circledR}$ International Patient Assistance Program (GIPAP). She was started on imatinib $400 \mathrm{mg} / \mathrm{d}$ in June 2005, and achieved complete hematological response in September 2005 and complete cytogenetic remission (CCyR) in June 2006. In February 2007 she wanted to become pregnant. Qualitative PCR was performed in March 2007, which was negative for the BCRABL gene rearrangement. Following patient consultation, imatinib treatment was withdrawn in April 2007 and subcutaneous (SQ) interferon- $\alpha$ was initiated at a dose of 3 $\mathrm{MU} / \mathrm{m}^{2} 5$ times/week.

Contraception was then stopped and 2 months later she was pregnant. The patient remained on interferon- $\alpha$ through out her pregnancy, without the need for dose reduction due to side effects. The pregnancy was carefully monitored in conjunction with the patient's obstetricians and she delivered a 1540-g boy in November 2007 via a Caesarian section at 33 weeks of gestation. The premature birth was due to pre-eclampsia. As a neonate the child was diagnosed with a patent foramen ovale and patent ductus arteriosus, which were considered complications of the premature delivery. The child then developed grade 3 hyaline membrane disease and hospital-acquired pneumonia. The congenital heart lesions resolved without intervention and the child fully recovered from his pulmonary complications.

The patient remained in CCyR for the duration of her pregnancy. Imatinib was reinstituted post delivery and the patient was advised not to breastfeed. The patient maintained CCyR and exhibited a continuous decrease in her BCR-ABL transcript level, although she still did not achieve a major molecular response (not adjusted to the international scale).

The patient's child was evaluated by a geneticist at age 3 years. The boy achieved normal developmental milestones, but was just below the third percentile for height and weight - he was, however, proportional. In terms of morphology, the child had clinodactyly, short fifth fingers, and slightly downward slanting palpebral fissures, but otherwise appeared normal.

\section{Case 2}

A 15-year-old female was diagnosed with Philadelphia chromosome-positive chronic-phase CML in 2004. Her symptoms included fatigue, peripheral edema, and bilateral hip pain. She presented with a WBC count of $347 \mathrm{x}$ $10^{9} / \mathrm{L}, \mathrm{Hb}$ of $6.0 \mathrm{~g} / \mathrm{dL}$, and a Plt count of $16 \times 10^{9} / \mathrm{L}$. Her 
differential count included 27\% neutrophils, $11 \%$ metamyelocytes, $45 \%$ myelocytes, and 3\% blasts. Her bone marrow was hypercellular without an increase in the blast count. Clinical examination showed that her spleen was enlarged to $4 \mathrm{~cm}$ below the costal margin. She was initially started on hydroxyurea $1.5 \mathrm{~g} / \mathrm{d}$ p.o. until imatinib could be procured via the GIPAP program. She achieved complete hematological remission after 3 months of treatment and cytogenetic remission after 12 months. After 18 months of treatment she had not achieved major molecular response. The imatinib dose was not increased because the patient developed neutropenia, which required a dose interruption.

In October 2009 (at age 21 years), having subsequently attained major molecular response, the patient discovered that she was 8 weeks pregnant. The treatment options were discussed with the patient and she decided to continue taking imatinib $400 \mathrm{mg} / \mathrm{d}$ during the pregnancy. The pregnancy was carefully monitored in conjunction with her obstetricians and she delivered a boy in March 2010 via Caesarian section, which was indicated due to intrauterine growth restriction. At birth the infant weighed $1980 \mathrm{~g}$ and had APGAR scores of 9 and 10. The child was evaluated by a geneticist and except for clinodactyly and low-set ears the child was morphologically normal. The mother was advised against breastfeeding.

\section{Discussion}

Treating patients with CML that wish to become pregnant is challenging for a number of reasons. There is no therapy that can be offered to a pregnant woman that is both completely safe and effective, and clinicians are therefore faced with the challenge of balancing the safety of the mother and treating her malignancy against the safety of the unborn child. Data on pregnancy outcomes in patients treated with imatinib are limited. One of the largest collections of data on the effect of imatinib on pregnancy outcome was compiled by Pye et al. [7]. They obtained data on 180 pregnancies in patients receiving imatinib from attending doctors that reported to the Novartis Pharmaceutical Company in Switzerland, the Hammersmith Hospital in London, or the M. D. Anderson Cancer Center in Huston. Fetal abnormalities were observed in 12 cases. A matter of great concern highlighted by the researchers was the increased preponderance of bony abnormalities, which indicated a potential correlation with imatinib treatment. Both of the presented patients' children had clinodactyly, which can be considered a normal variant or a minor malformation, as its incidence varies from $1 \%$ to 19\% [8]. Clinodactyly was not considered to be causally linked to the use of imatinib in the presented cases.

Data from the Stop Imatinib (STIM) Trial indicate that imatinib can be discontinued in a select subgroup of patients that achieve complete molecular response and maintain it for 2 years [9]. This may well be the ideal method to manage a pregnancy, but may not be applicable to all patients. Patients with disease that is not optimally controlled, as per the European LeukemiaNet (ELN) guidelines [2], may be even more difficult to manage. In such cases continuation of therapy with close monitoring of the pregnancy may facilitate continuation of effective therapy, but pose the risk of adverse fetal outcome.

Other modalities of therapy that have been used include hydroxyurea, interferon- $\alpha$, and leukapheresis [10-12], each of which is potentially problematic during pregnancy, although interferon may be a safer option though less efficacious than imatinib $[13,14]$. We described 2 CML patients that gave birth following different approaches to the management of their pregnancies. Case 1 was managed in what may be considered a more classical approach-interruption of imatinib and the use of interferon. This option resulted in a successful pregnancy without the loss of disease control. Case 2 was more complex because the patient failed to achieve an optimal response, according to published guidelines [2] Consequently, there was concern about disease progression and resistance should therapy be interrupted. In the light of normal fetal ultrasonographic findings at the end of the first trimester, and consultation with colleagues and the patient, imatinib was continued during the pregnancy with close monitoring, which resulted in a favorable outcome.

According to Pye et al. [7] and preclinical animal models [6], it is important that women be made aware of the potential complications of therapy for CML during pregnancy; however, in selected cases continuation of imatinib with close monitoring of the pregnancy may facilitate control of the disease and delivery of a normal infant.

\section{Acknowledgement}

The authors thank Dr. Daleen Struwig, University of the Free State, Faculty of Health Sciences, for technical and editorial preparation of the manuscript for publication.

\section{Conflict of Interest Statement}

None of the authors have any conflicts of interest, including specific financial interests, relationships, and/or affiliations, relevant to the subject matter or materials included. 


\section{References}

1. O'Brien SG, Guilhot F, Larson RA, Gathmann I, Baccarani M, Cervantes F, Cornelissen JJ, Fischer T, Hochhaus A, Hughes T, Lechner K, Nielsen JL, Rousselot P, Reiffers J, Saglio G, Shepherd J, Simonsson B, Gratwohl A, Goldman JM, Kantarjian H, Taylor K, Verhoef G, Bolton AE, Capdeville $\mathrm{R}$, Druker BJ. Imatinib compared with interferon and lowdose cytarabine for newly diagnosed chronic-phase chronic myeloid leukemia. N Engl J Med 2003; 348: 994-1004.

2. Baccarani M, Cortes J, Pane F, Niederwieser D, Saglio G, Apperley J, Cervantes F, Deininger M, Gratwohl A, Guilhot F, Hochhaus A, Horowitz M, Hughes T, Kantarjian H, Larson R, Radich J, Simonsson B, Silver RT, Goldman J, Hehlmann R. Chronic myeloid leukemia: An update of concepts and management recommendations of European LeukemiaNet. J Clin Oncol 2009; 27: 6041-6051.

3. Deininger MWN, O'Brien SG, Ford JM, Druker BJ. Practical management of patients with chronic myeloid leukemia receiving imatinib. J Clin Oncol 2003; 21(8): 1637-1647.

4. Marin D, Bazeos A, Mahon FX, Eliasson L, Milojkovic D, Bua M, Apperley JF, Szydlo R, Desai R, Kozlowski K, Paliompeis C, Latham V, Foroni L, Molimard M, Reid A, Rezvani K, de Lavallade H, Guallar C, Goldman J, Khorashad JS. Adherence is the critical factor for achieving molecular responses in patients with chronic myeloid leukemia who achieve complete cytogenetic responses on imatinib. J Clin Oncol 2010; 28: 2381-2388.

5. O'Brien SG, Guilhot F, Goldman JM, Hochhaus A, Hughes TP, Radich JP, Rudoltz M, Filian J, Gathmann I, Druker BJ, Larson RA. International Randomized Study of Interferon Versus STI571 (IRIS) 7-year follow-up: Sustained survival, low rate of transformation and increased rate of major molecular response in patients with newly diagnosed chronic myeloid leukemia in chronic phase treated with imatinib. Blood 2008; 112: Abstract 186.
6 Novartis Pharmaceutical Company. Gleevec ${ }^{\circledR}$ (imatinib) prescribing information. Available at www.pharma. us.novartis.com/product/pi/pdf/gleevec_tabs.pdf (Accessed 3 December 2012)

7. Pye SM, Cortes J, Ault P, Hatfield A, Kantarjian H, Pilot R, Rosti G, Apperley JF. The effects of imatinib on pregnancy outcome. Blood 2008; 111: 5505-5508.

8. Flatt AE. The troubles with pinkies. BUMC Proceedings 2005; 18: 341-344.

9. Mahon FX, Réa D, Guilhot J, Guilhot F, Huguet F, Nicolini F, Legros L, Charbonnier A, Guerci A, Varet B, Etienne G, Reiffers J, Rousselot P. Discontinuation of imatinib in patients with chronic myeloid leukaemia who have maintained complete molecular remission for at least 2 years: The prospective, multicentre Stop Imatinib (STIM) trial. Lancet Oncol 2010; 11: 1029-1035.

10. Lipton JH, Derzko CM, Curtis J. Alpha-interferon and pregnancy in a patient with CML. Hematol Oncol 1996; 14: 119-122.

11. Patel M, Dukes IA, Hull JC. Use of hydroxyurea in chronic myeloid leukemia during pregnancy: A case report. Am J Obstet Gynecol 1991;165: 565-566.

12. Ali R, Ozkalemkaş F, Ozkocaman V, Ozçeklic T, Ozan U, Kimya Y, Tunali A. Successful pregnancy and delivery in a patient with chronic myelogenous leukemia (CML), and management of CML with leukapheresis during pregnancy: a case report and review of the literature. Jpn J Clin Oncol 2004; 34: 215-217.

13. PonsJC, Lebon P, Frydman R, DelfraissyJF. Pharmacokinetics of interferon-alpha in pregnant women and fetoplacental passage. Fetal Diagn Ther 1995; 10: 7-10.

14. Bristol-Myers Squibb Company. Hydrea ${ }^{\circledR}$ (hydroxyurea) prescribing information. Available at http://packageinserts. bms.com/pi/pi_hydrea.pdf (Accessed 3 December 2012). 